\title{
Alpha-linolenic acid supplementation in Tris extender can improve frozen-thawed bull semen quality
}

\begin{abstract}
The study was conducted to evaluate the effects of $\alpha$-linolenic acid (ALA) on frozen-thawed quality and fatty acid composition of bull sperm. For that, twenty-four ejaculates obtained from three bulls were diluted in a Tris extender containing 0 (control), 3, 5, 10 and $15 \mathrm{ng} / \mathrm{ml}$ of ALA. Extended semen was incubated at $37^{\circ} \mathrm{C}$ for $15 \mathrm{~min}$, to allow absorption of ALA by sperm cell membrane. The sample was chilled for $2 \mathrm{~h}$, packed into $0.25 \mathrm{-ml}$ straws and frozen in liquid nitrogen for $24 \mathrm{~h}$. Subsequently, straws were thawed and evaluated for total sperm motility (computer-assisted semen analysis), membrane functional integrity (hypo-osmotic swelling test), viability (eosin-nigrosin), fatty acid composition (gas chromatography) and lipid peroxidation (thiobarbituric acid-reactive substances (TBARS)). A higher $(\mathrm{p}<0.05)$ percentage of total sperm motility was observed in ALA groups $5 \mathrm{ng} / \mathrm{ml}(47.74 \pm 07)$ and 10 $\mathrm{ng} / \mathrm{ml}(44.90 \pm 0.7)$ in comparison with control $(34.53 \pm 3.0), 3 \mathrm{ng} / \mathrm{ml}(34.40 \pm 2.6)$ and 15 $\mathrm{ng} / \mathrm{ml}(34.60 \pm 2.9)$. Still, the $5 \mathrm{ng} / \mathrm{ml}$ ALA group presented a higher $(\mathrm{p}<0.05)$ percentage of viable sperms $(74.13 \pm 0.8)$ and sperms with intact membrane $(74.46 \pm 09)$ than all other experimental groups. ALA concentration and lipid peroxidation in post-thawed sperm was higher in all treated groups when compared to the control group. As such, the addition of 5 $\mathrm{ng} / \mathrm{ml}$ of ALA to Tris extender improved quality of frozen-thawed bull spermatozoa.
\end{abstract}

Keyword: ALA; Tris extender; Bull sperm 